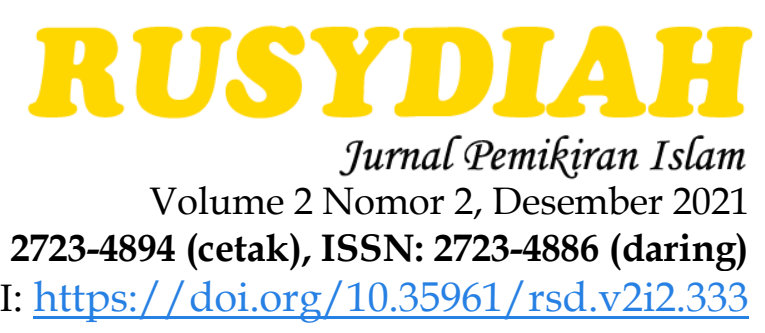

\title{
STUDY TEORI MUTUALISME PAUL F. KNITTER DALAM HUBUNGAN ANTARUMAT BERAGAMA DI INDONESIA
}

\author{
Waluyo \\ Universitas Nahdlatul Ulama Surakarta \\ walwaluyo968@gmail.com \\ Sahal Abidin \\ Universitas Nahdlatul Ulama Surakarta \\ sahal_abidin@yahoo.co.id
}

\begin{abstract}
Abstrak
Agama merupakan peratuan yang dibuat oleh Tuhan, melalui perantara-Nya disampaikan kepada setiap manusia. Dalam perjalannannya agama menjadi way of life pada setiap pemeluknya. Selain itu agama menjadi pegangan yang tidak dapat diganggu gugat oleh orang lain. Kenyakinan dalam kebenaran agamanya semakin mengakar dan menyebabkan truth claim. Klaim kebenaaran dan penolakan kebenaran yang lain adalah implementasinya. Adanya klaim kebenaran dan berusaha menyelamatkan yang lain dari kesesatan merupakan misioner. Fenomenologi menjawab konflik antaragama didasari atas ketikadilan kesejahteraan dan kesenjangan sosial serta keinginan kesetaraan politik. Husserl melalui fenomenologinya memberikan pengertian bahwa ada kebenaran di balik sesuatu yang tampak. Fenomenologi menangkap bahwa konflik antaragama tidak sepenuhnya disebabkan perbedaan agama. Selain klaim kebenaran dan keselamatan ketidakadilan masalah perekonomian, perpolitikan, sosial dan kebudayaan merupakan sumber dari konflik. Konflik yang terjadi semakin besar karena adanya klaim yang menyundut konflik antaragama, sehingga setiap pemeluk agama akan merasa terusik. Mutualisme memberikan teori hubungan antaragama yang dialog mutual. Teori ini atas dasar pandangan orang Kristen melihat agama di luar gereja. Berdasar kesamaan yang ada pada setiap agama mutualisme memproyeksikan hubungan yang saling menguntungkan. Latar belakang konflik ialah adanya ketidakadilan pada bidang politik, ekonomi dan budaya, maka tawaran Knitter yang dapat diterapkan di Indonesia adalah pola hubungan yang mutual.
\end{abstract}

Kata kunci : agama, hubungan antaragama, mutualisme.

Rusydiah: Jurnal Pemikiran Islam, Vol. 2, No. 2, Desember 2021 


\begin{abstract}
Religion is an arrangement made by God, through His intermediary delivered to every human being. In its journey, religion becomes a way of life for each of its adherents. In addition, religion is a guide that cannot be contested by others. Belief in the truth of his religion is getting more and more rooted and causes truth claims. Claims of truth and denial of other truths are their implementation. To claim truth and to try to save others from misguidance is missionary. Phenomenology answers interreligious conflicts based on welfare justice and social inequality as well as the desire for political equality. Husserl through his phenomenology gives an understanding that there is truth behind something that appears. Phenomenology captures that interreligious conflicts are not entirely caused by religious differences. In addition to claims of truth and salvation, injustice in the economic, political, social and cultural fields is a source of conflict. The conflicts that occur are getting bigger because of claims that fuel inter-religious conflicts, so that every religious adherent will feel disturbed. Mutualism provides a theory of interreligious relations which is a mutual dialogue. This theory is based on the view of Christians looking at religion outside the church. Based on the similarities that exist in each religion, mutualism projects a mutually beneficial relationship. The background of the conflict is the existence of injustice in the political, economic and cultural fields, so Knitter's offer that can be applied in Indonesia is a pattern of mutual relations
\end{abstract}

Keywords : religion, interreligious relations, mutualism.

\title{
PENDAHULUAN
}

Agama merupakan peraturan-peraturan Tuhan yang diberikan kepada utusan untuk kemudian ditanamkan kepada manusia, sehingga pesan-pesan yang dikandung dalam ajarannya mutlak. Agama merupakan sistem sosial dibuat oleh penganut-penganutnya yang berproses pada kekuatan-kekuatan non empiris yang dipercayainya dan didayagunakannya untuk mencapai keselamatan bagi mereka. ${ }^{1}$ Pendapat lainnya mengatakan bahwa agama ialah memaksimalkan supraempiris untuk hal-hal non empiris atau supra empiris. ${ }^{2}$ Akan tetapi yang menjadi persoalan bagi manusia adalah fenomena keberagaman agama berbeda. Dari sini muncul keyakinan terhadap Tuhan dan ajaran-ajaranya yang pada akhirnya lahir truth of claim atas agama yang diimani. ${ }^{3}$

Mengakarnya truth of claim pada setiap individu tidak hanya sekali-kali memberikan preposisi yang menguntungkan baik dari segi teologi ataupun sosial, namun akan menimbulkan sikap fanatik (eksklusif) yang berlebihan yang dapat menghantam sendi keimanan. Dalam pengantar buku Teologi Inklusif Cak Nur yang ditulis Sukidi, ia menjelaskan anggapan bahwa kebenaran dan keselamatan hanya

${ }^{1}$ Hendropuspito, D. Sosiologi Agama (Yogyakarta: Pustaka Pelajar, 1986), h. 32.

${ }^{2}$ Thomas F. O'deo, Sosiologi Agama (Jakarta: PT Rajawali, 1985), h. 139.

${ }^{3}$ Mukti Ali, Pandangan Pluralism Sebagai Jalan Pemersatu, Jurnal Ijtihad, vol. 5 (Jakarta: UIN Syarif Hidayatullah 2003), h. 5. 
milik agama tertentu. ${ }^{4}$ Angapan ini berimplikasi sebuah penyataan bahwa agama lain adalah sesat, hal tersebut masuk dalam wilayah alam bawah sadar pemeluk agama tertentu. Eksklusif merupakan cara pandang yang digunakan dalam melihat agama di luar dirinya, pemahaman ini menjadikan sikap toleransi yang sempit. ${ }^{5}$ Penilaian terhadap agama lain dengan menggunakan agama kita adalah hal yang mustahil. Justru akhirnya setiap pemeluk agama mengibarkan bendera kebenaran dan keselamatan.

Keberadaan agama-agama menjadi realitas yang tidak dapat dinafikan, sehingga dalam hal ini perbedaan konsepsi antaragama menjadi hal yang wajar. Keimanan adalah hubungannya dengan Tuhan, yang kemudian direinterpretasi baik secara luas maupun sempit. Kemana harus menjelmakan dalam betuk kelompok, tidak lagi kepercayaan melainkan menjadi fenomena yang harus terorganisasi. Truth of claim berefek pada misionaris/dakwah yang tidak lagi mementingkan kualitas iman melainkan kuantitas jumlah anggota. Akibatnya Truth of claim yang terjadi pada setiap agama menimbulkan konflik, misalnya pergantian agama yang awalnya dipandang sah dan tidak masalah, tetapi karena adanya organisasi menjadi suatu masalah. Contoh yang lain terjadi di Bantul ketika Romo Mangun Wijaya membangun jalan. Berita ini termuat dalam sebuah majalah, hal ini mendapat tudingan bentuk Kritenisasi dari orang Islam. ${ }^{6}$

Berbicara konflik antarumat beragama biasanya terkait dengan aspek sosial dan ekonomi di Indonesia. Konflik yang paling mencolok adalah antaraagama Islam dan Kristen walaupun tidak menutup kemungkinan agama lain juga berpotensi, namun antara Islam dan Kristen sering terjadi. ${ }^{7}$ Setidaknya ada tiga dimensi yang harus diperhatikan, ketiga dimensi dari dialog tersebut yakni, melihat dimensi intern agama, kondisi sosial, ekonomi, politik dan budaya sebagai dimensi ekstern, dan cara menyelesaikan konflik.

Kerusuhan atas nama agama sepertinya belum akan segera berakhir. Negeri ini seakan-akan tak pernah bosan untuk saling menumpahkan darah. Berebut surga dengan klaim sesat menyesatkan seakan menjadi cara yang paling tepat untuk dilakukan. Tragedi lama pun pecah kembali di Sampang antara umat Islam beraliran Sunni dan Syiah. "Bom waktu" itu pun tampaknya tak pernah bosan mengincar korban. Faktornya sikap beragama yang ekstrim, radikal, merusak,

${ }^{4}$ Ibid

${ }^{5}$ Sukidi Mulyadi, Teologi Inklusif Cak Nur (Jakarta: Kompas, 2001), h. xi.

${ }^{6}$ Arief Budiman, Dimensi Sosial Ekonomi dalam Konflik. Antar Agama di Indonesia,(Yogyakarta: DIAN/Interfidei, 1995), h. 184.

${ }^{7}$ Ibid, h. 182. 
sampai melakukan pembunuhan. Sikap merusak, memukuli, membakar, atau perilaku anarkistis lainnya terhadap mereka yang berbeda bagaimana pun jelas tidak bisa dibenarkan, baik dalam sisi hukum di Indonesia maupun agama.

Semua yang terjadi menunjukkan akan pentingnya dialog antarumat beragama. Dialog antarumat beragama mengantarkan pemahaman keberagamaan yang tidak mungkin terhindarkan (pluralitas), sehingga muncul sikap keberagamaan yang memahami keberadaan agama lain, hingga sikap simpati dan empati. Ada banyak konsep tentang memandang agama lain, misalnya Karl Rahner dengan konsep anonymaos Christians. ${ }^{8}$ Karl Rahner adalah seorang teologi Katolik yang berhaluan inklusif menyebutkan anonymous Christians, yaitu orang non Kristen yang selamat karena hidup dalam ketulusan hati pada Tuhan. ${ }^{9}$ Pandangan Karl Rahner ialah interpretasi dari sikap inklusif yang senada dengan pandangan Cak Nur. ${ }^{10}$ Menurut Cak Nur Islam artinya pasrah dan barang siapa memiliki sikap pasrah maka dia akan selamat. Antar agama memiliki perbedaan pada level yang terlihat atau eksplisit akan tetapi pada tataran implisitnya relatif sama, oleh karenanya ada istilah banyak jalan menuju Tuhan. ${ }^{11}$

Percakapan keseharian yang di dalamnya ada dialog antarumat beragama menghadapi kondisi jenuh, karena hanya akan membuang-buang energi. Jalan keluar untuk mengatasinya lingkaran buta dialog teologis dengan membicarakan dan memasukan agenda kerjasama sosial agama-agama. ${ }^{12}$ Hal ini sebagai pengabdian agama atas keprihatian sesama. Sumartana dalam Komarudin sebagai tokoh yang sangat memperhatikan hubungan antaragama menekankan dialog, yang menjadi tantangan kemanusian tidak sekedar beauty contest doktrin-doktrin normatif, sebab yang diperlukan respon manusia terhadap realitas yang ada. ${ }^{13}$ Survival dalam beragama yang sesungguhnya bukan hanya permasalahan pemurnian doktrin agama, melainkan kemampuan agama menjawab tantangan yang ada. Tawaran teori mutualisme dari Knitter selain menciptakan keharmonisan hubungan antaragama. Teori ini lebih dari sekedar sikap toleransi terhadap agama lain, karena mutualisme merupakan real action (proposal pluralis). Mutualisme, yang Knitter mengartikannya dialog antaragama yang mutual.

\footnotetext{
${ }^{8}$ Paul F Knitter, Introduducing the Teologies of Religions (New York: Marynoll, 2002), h. 72.

9 Jhon Hick, God Has Many Names (Philadelpea: The Westminster Press, 1980), h. 34.

10 Sukidi Mulyadi, Teologi Inklusif Cak. Nur, h. xxxiv.

${ }^{11}$ Nurcholish Majid, Tiga Agama Satu Tuhan (Mizan: Bandung, 1999), h. xix.

${ }^{12}$ Komaruddin Hidayat dan Muhammad Wahyuni Nafis, Agama Masa Depan Perspektif Filsafat Perenial (Jakarta: Paramadina, 1995), h. xxxvii.

${ }^{13}$ Ibid, h. xxxviii.
} 


\section{METODE}

Tulisan ini merupakan hasil library research dimana data dalam penelitian diperoleh dari sumber berupa tulisan, data dapat berupa buku, kamus, majalah dan lain-lainnya yang berkaitan dengan hubungan antar agama. Peneliti menggunakan pendekatan kualitatif yakni penelitian dengan hasil data deskriptif. Content analysis menjadi metode dalam penelitian, dimana pembahasan yang mendalam diperoleh dari data informasi cetak atau tertulis. Analisis ini mendefinisikan suatu metode untuk menganalisi komunikasi dari pesan yang tampak. Untuk memperdalam masalah konflik melalui fenomenologi Husserl, dimana memberikan pengertian bahwa ada kebenaran dibalik sesuatu yang tampak. Fenomenologi menangkap bahwa konflik antaragama tidak sepenuhnya disebabkan perbedaan agama.

\section{HASIL DAN PEMBAHASAN}

\section{Biografi Paul F. Knitter}

Knitter lahir di Chicago, Amerika Serikat pada tahun 1939. Sebagai seorang teolog Katolik di Roma dia berperan mengembangkan dialog antaragama. Knitter yang merupakan tokoh hubungan antaragama sering dikenal sebagai seorang yang pluralis. Sebagai pendukung pluralism, seperti halnya tokoh yang lain seperti Alan Race dan John Hick. Selain mendukung konsep pluralisme Knitter juga giat dalam dialog antar iman.

Perjalanan dialog Knitter, dimulai dengan monolog kehidupannya yang indah. Sebagai seorang teolog Katolik yang kuat dengan sikap eksklusifnya, dia menganggap kepercayaan orang lain tidak banyak kepentingannya dan tidak diperhatikan karena dia ingin berbicara dengan mereka hanya karena dia ingin memurtadkannnya (memasukkan Kristen/Misioner). ${ }^{14}$ Keinginan besarnya menjadi misioner terpenuhi di tahun 1958. Sebelumnya selama empat tahun sekolah persipan Pendeta dan dua tahun masa percobaan. Dilogical odyssey Knitter

${ }^{14}$ Lidya Kambo Tandirerung, Liberative Dialogue a Comparative Analysis of the Proposal of Paul Knitter and Farid Esack for Liberative Dialogue of Religions and Their Contribution to Muslim-Chistian Relation in Indonesia (Yogyakarta: UGM, 2004), h. 17. 
berhubungan dengan keberadaan dua dasar tentang agama dan penderitaan (the Religious Othersandthe Suffering Others). ${ }^{15}$

Sebagai misioner Katolik, Knitter melihat agama lain bukan untuk berhubungan, melainkan dengan maksud mendakwahkan agama Katolik (memasukkan ke Katolik). Dogma gereja ${ }^{16}$ yang kental dengan pandangan eksklusif mewarnai pola pikirnya. Sebuah dogma yang menolak kepercayaan di luar gereja ${ }^{17}$ baik keberadaannya maupun kebenarannya (replacement total). Extraecclesium nulla salus menjadi sebuah pegangan yang kuat bagi seorang teolog begitu juga Knitter, yang membuatnya semakin kuat dengan tafsiran secara eksklusif bahwa tidak ada kebenaran di luar gereja.

Knitter memulai studinya di Roma, di Pontifical Gregorian University, dua tahun setelah konsili Vatican II, 11 Oktober 1962,18 oleh Paus Yohannes XXIII.19 Declaration on the relationship of the Church Non-Christians Religions (Noestra aetate) ${ }^{20}$ memberi Knitter banyak arti penting. Isi deklarasi yang merevisi prinsip extra ecclesium nulla salus ke arah tafsiran yang inklusif. Di mana kebenaran dan keselamatan tidak menjadi milik agama Kristen secara monopoli dengan iman kepada Yesus sebagai wujud eksplisitnya. Knitter menemukan pernyataan positif tentang kebenaran dan nilai dari Hindu, Buddha dan Islam dari dokumen gereja.

Perubahan besar dari Knitter terjadi di Roman Catholic theology of religions. ${ }^{21}$ Di Roma dia memperkuat pandangannya ke arah inklusif. Teologi Rahner banyak memberi pengaruh di universitas, saat ia berjumpa dengan Rahner. Perkenalannya dengan Rahner saat Rahner datang menjadi tamu seorang professor. Rahner memberi angin segar dan udara bebas untuk Knitter. ${ }^{22}$ Khususnya hubungan tentang ide Kristen melihat agama lain sebagai jalan keselamatan di luar gereja. Pengaruh Rahner yang disampaikan pada Knitter saat mendiskripsikan tentang teologi:

\footnotetext{
${ }^{15}$ Paul F. Knitter, One Erath Many Religions: Multifaith Dialogue and Global Responding (New York: Orbis Books,1995), h. 3.

${ }^{16}$ Kata Geraja, maksudnya ialah sebuah bangunan tempat ibdah agama Kristen (Gereja).

${ }^{17}$ Kata gereja, memiliki arti agama Kristen, hal ini dimaksud untuk menghindari dari petanyaan sekte dari Kristen, agar lenih umum dalam penyebutan (Kristen umum baik Protestan maupun Katholik ataupun yang lain).

${ }^{18}$ Lidya Kambo Tandirerung, Liberative Dialogue a Comparative Analysis, h. 18.

${ }^{19}$ George B. Grose dan Benjamin J Hubbard, Tiga Agama Satu Tuhan (Bandung: Mizan, 1998), h. xxxvii.

${ }^{20}$ Sukidi Mulyadi, Teologi Inklusif Cak Nur, h. xxxiv.

${ }^{21}$ Paul F. Knitter, One Erath Many Religions: Multifaith Dialogue and Global Responding, h. 5.

22 Lidya Kambo Tandirerung, Liberative Dialogue a Comparative Analysis, h. 19.
} 
"A Catholik theology ultimately cannot strive to be particularly original: to say something which no one else has ever said. Rahner, a theologian's obligation, duty, and intent aim at guarding and interpreting the message of Jesus, the relevation of God, and the teaching of the Chruch, and to make it intelligible to one's contemporary." 23

Pernyataan ini senada dengan isi dari konsili Vatikan yang ke-II, saat deklarasi perihal hubungan gereja dengan agama di luar Kristen. Salah satu yang dapat diambil dari Rahner oleh Knitter adalah konstruksi positif tentang kedudukan wanita dan diskriminasi alam. Knitter merupakan Rahnerian, salah satu pemikiran yang diambil dari Rahner ialah anonymous Christians. ${ }^{24}$ Anonymous Christians yaitu orang non Kristen yang selamat karena hidup dalam ketulusan hati pada Tuhan ${ }^{25}$. Pandangan Karl Rahner ialah interpretasi dari sikap inklusif. Senada dengan pandangan Rahner, Cak Nur juga mendiskripsikan ulang pemahaman tentang Islam. Dengan mengadopsi pemikiran Rahner tentang anonymous Christians. Menurut Cak Nur al-Islam artinya pasrah dan barang siapa memiliki sikap pasrah maka dia akan selamat. ${ }^{26}$

\section{Karya dan Pemikiran}

Pemikiran Knitter banyak tertuang dalam buku-bukunya. Untuk mengetahui bagaimana jalan pemikiran dan teori-teori hubungan antarumat beragama maka perlu merujuk beberapa karyanya. Adapun beberapa karya dari Knitter yang di dalamnya memuat teori hubungan dengan agama lain, banyak termuat dalam buku-buku di bawah ini:

1. No Other Name? A Critical Survey of Christian Attitudes Toward the World Religions.

Buku yang terbit pada tahu 1985, membahas tentang pemetaan pemikiran Kristen mengenai agama-agama di luarnya. Kosep yang dibangun oleh Knitter memiliki fokus, metode dan menghasilkan kesimpulan yang mirip dengan buku karangan Alan Race, yang merupakan awal dari dialog antaragama. Letak perbedaannnya konsep Alan yakni tipologi eksklusivisme-

\footnotetext{
${ }^{23}$ Ibid, h. 19.

24 Paul F Knitter, Introduducing the Teologies of Religions (New York: Marynoll, 2002), h. 72.

${ }^{25}$ Sukidi Mulyadi, Teologi Inklusif Cak, h. xxxiv.

${ }^{26}$ Ibid, h. xxxiv.
} 
inklusivisme-pluralisme, sedangkan Knitter merinci ada empat tipologi, adapun pemikiran Knitter yakni: ${ }^{27}$

a. Model Konservatif-Injili, tipologi yang meyakini bahwa hanya ada satu agama yang benar dan kebenaran hanya ada dalam agama Kristen, salah seorang menggunakan tipologi ini ialah Karl Barth.

b. Model Protestan Arus-Utama, merupakan pandangan bahwa keselamatan hanya ada dalam Kristus. Ungkapan ini mengatakan bahwa Tuhan dapat ditemukan dalam semua agama. Pendektan dalam model ini mengungapkan bahwa meskipun Tuhan dapat ditemukan melalui beberapa agama namun hanya dalam Kristus keselamatan diemukan. Tokoh yang dikenal dengan konsep ini di antaranya Paul Althaus, Emil Brunner, dan Wolfhart Pannenberg.

c. Model Katolik, tipoloi ini beranggapan bahwa jalan menuju Tuhan ada banyak, akan tetapi hanya Kristus yang secara normatif dalam berbagian jalan yang ditempuh. Menurut Knitter, ia mengatakan bahwa Hans Kung dan Karl Rahner sebagai contoh pemikir model ini.

d. Model Teosentris, model pendekatan yang percaya bahwa banyak jalan menuju pusat, yakni Tuhan sendiri sebagai jalannya. Hal ini mengungkapkan bahwa peran agama non Kristen sebagai jalan yang diafrimasi konsep ini. Selain Knitter, beberapa teolog lain yang diposisikan di dalam model ini adalah John Hick, Raimundo Panikkar, dan Stanley Samartha.

2. One Earth Many Religions (Satu Bumi Banyak Agama).

Dalam One Earth Many Religions ia mengatakan bahwa model yang digunakan pada buku sebelumnya kurang sesuai. Model eksklusifismeinklusifisme-pluralisme dalam model pendekatan Alan Race dianggap Knitter lebih tepat. ${ }^{28}$ Knitter sebelumnya menyatakan bahwa dirinya menganut posisi pluralisme yang menyatakan bahwa agama-agama merupakan jalan-jalan yang berbeda menuju satu tujuan, yang dalam bahasa Kristen disebut Allah. Akan tetapi, Knitter menyatakan bahwa dirinya telah melampaui posisi pluralisme yang teosentris yang dianut sebelumnya, yakni dengan posisi soteriosentrisme. ${ }^{29}$

${ }^{27}$ Paul F. Knitter, No Other Name (New York: Orbis Books, 1985), h. 9.

28 Paul F. Knitter, Satu Bumi Banyak Agama (Jakarta: BPK Gunung Mulia, 2004), h. 20-24.

${ }^{29}$ Ibid. h. 35-36. 
Soteriosentrisme dari asal kata dalam dalam bahasa Yunani soter yang berarti keselamatan. ${ }^{30}$ Soteriosentris secara etimologis berarti berpusat pada keselamatan. Model pluralisme menyatakan tenang satu realitas Tuhan (disebut The Real oleh John Hick) atau Tuhan dalam agama Abrahamik, maka soteriosentrisme menjadikan konteks penderitaan umat manusia dan penderitaan alam (krisis ekologis) sebagai pusat. Penderitaan yang dialami umat manusia dan kerusakan alam haruslah menjadi fokus perhatian dan sasaran dari agama-agama yang ada. Manusia dan alam yang menderita perlu mendapatkan keselamatan yakni terbebas dari derita yang mereka alami. Di sini, paham keselamatan dalam keKristenan diberikan pemaknaan baru oleh Knitter.

3. Introducingthe Teologies of Religions

Dalam buku Introducing the Teologies of Religions yang diterbitkannya tahun 2002, dia mendefinisikan pandangan tentang (pendekatan) agama melalui empat pilar, yakni:

a. The Replacement Model (Model Penggantian) "Only One True Religion". ${ }^{1}$

Model pergantian atau penolakan menurut Knitter ialah model yang menganggap agama yang lain sesat dan tertolak.

b. The Fulfillment Model (Model Pemenuhan) "The Only Fulfills The Many".32

Model Pemenuhan, yang bersumber pada gagasan bahwa Tuhan hadir di dalam agama di luar agama Kristen, akan tetapi kekristenan dalam hal ini Yesus Kristus berperan sebagai penyempurna agama lainnya.

c. The Mutuality Model (Model Mutualitas) "Many True Religion Called To Dialog". 33

Model Mutualitas memiliki prinsip yang menyatakan bahwa seluruh agama memiliki pondasai atau dasar yang sama, paling tidak dalam beberapa hal ada kesamaan. Dari sinilah yang memungkinkan adanya dialog secara mutual.

d. The Acceptante Model (Model Penerimaan) "Many True Religions:So Be It". 34

\footnotetext{
${ }^{30} \mathrm{Ibid}$

${ }^{31}$ Paul F. Knitter, Introducing the Teologies of Religions, h. 16.

${ }^{32}$ Ibid, h.61.

${ }^{33}$ Ibid, h.107.

${ }^{34}$ Ibid, h. 170 .
} 
Model penerimaan ialah menerima kebenaran agama di luar Kristen (pluralisme). Model yang terakhir ini menekankan bahwa setiap agama adalah jalan menuju kebenaran, true and salvation menjadi hak semua agama.

\section{Teori Mutualisme Paul F. Knitter}

Seperti yang telah dijelaskan sebelumnya tentang pengertian mutualisme, bahwa mutualisme memiliki pendekatan utama bahwa kasih Tuhan bersifat universal yang membawa konsekuensi semua agama benar. Dengan dialog dapat dimanfaatkan secara bersama antar agama, inilah harapan dari model ini. Jembatan yang ditawarkan dalam dialog ini merupakan jembatan filosofis historis, jembatan ini menjadi lantaran melakukan dialog yang baik. Model pendekatan ini memiliki arti menafikan keyakinan dasar tentang partikularitas Yesus yang membawa konsekuensi eksklusif yakni tidak ada jalan lain bahkan menutup jalan lain. Anggapan bahwa semua agama memiliki dasar yang sama, jika tidak sama persis tetap ada beberapa kesamaan, inilah yang menjadi modal dasar dialog mutual.

Menurut Coward dialog harus berusaha menyatakan beberapa praanggapan yang menjadi dasar dialog tentang masa depan agama. Adapun enam pra-anggapan itu adalah: ${ }^{35}$ pengalaman realitas agama, pluralitas sebagai pentinganya kebebasan dan kehormatan terhadap yang lain, pluralitas sebagai alat, keterbatasan pengalaman agama dan kebutuhan komitmen bersama, toleransi kritis dan pentingnya moral, dialog kritis antaragama, studi kritis tentang agama untuk menerobos realitas transenden sosial.

Hubungan antarumat beragama menurut mutualisme Knitter, bahwa setiap agama dalam memandang agama yang lain tidak sekedar dalam batasan sikap toleransi akan keberadaan dan kesamaan kebenaran. Berdasarkan kesamaan kedudukan yang dimungkinkan terjadi dialog. Menurut Knitter dialog yang dilakukan dengan menjadikan mutualisme lebih dari sekedar teori. Kerjasama antarumat beragama menjadi proyeksi teori ini, seperti halnya pendapat Sukidi yang mengkritisi teologi inklusif Cak Nur yang hanya berhenti pada tataran konsep atau wacana toleransi. ${ }^{36}$

\footnotetext{
${ }^{35}$ Harold Coward, Pluralisme, Tantangan bagi Agama-agama (Yogyakarta: Kanisius, 1989), h. 185.

${ }^{36}$ Sukidi Mulyadi, Teologi Inklusif Cak Nur, h. xlii.
} 
Begitu juga Farid Esack dengan teori hermeneutik al Qur'an ${ }^{37}$ untuk melawan penindasan apartheid di Afrika Selatan. ${ }^{38}$ Hermeneutik menjadi salah satu metode Esack yang berkaitan dengan hubungan antaragama. Metode Esack merupakan gambaran di mana hubungan antaragama tidak sekedar dimaknai sebagai bentuk pengakuan kesamaan setiap agama, melainkan atas dasar kesamaan itu bersatu untuk kerjasama.

Sama halnya dengan Knitter, dengan teori mutualismenya Knitter memberikan metode dalam berdialog antarumat beragama yang saling menguntungkan. Mutualisme merupakan satu dari empat teori Knitter yang didasari pandangan agama Kristen terhadap agama di luarnya. Dilaog mutual berdasarkan kesamaan pada setiap agama mengantarkannya pada kerjasama. Kelebihan dari mutualisme ialah membawa proposal pluralis, sehingga pemaknaan pluralis tidak stagnant dalam wacana dan sikap toleransi.

Mutualisme memberi ruang bagi agama untuk menyentuh sisi di luarnya. Yakni mendekatkan agama dengan semua lini kehidupan baik politik, sosial, ekonomi budaya maupun lingkungan. Dialog mutual bukan untuk mencari siapa yang benar dan begitu juga sebaliknya, melainkan dialog antarumat beragama dalam menjawab persoalan kemanusiaan. Misalnya kemiskinan, lemahnya pendidikan, ketidakadilan politik dan kesenjangan sosial yang kesemuannya awal terjadinya konflik.

Maka konflik yang selama ini berkembang atas nama agama dapat dengan sendiri terkurangi. Kemiskinan, ketidakadilan serta kesamaan dalam politik dan tidak ada sekat-sekat budaya, melalui dialog mutual akan pudar. Konflik yang dilatarbelakangi oleh kesenjangan sosial dan diperkuat oleh truth claim setiap agama akan hilang menjadi hubungan dengan dialog mutual yang baik. Jadi yang menjadi kelebihan dari teori mutualisme dalam hubuangan antarumat beragama ialah, penekanan dari penerapan teori mutualisme. Dialog mutual dilakukan atas dasar persamaan yang ada dalam setiap agama untuk mencari keuntungan dalam kerjasama. Bentuk kerjasama ini sangat variatif, tidak monoton, melainkan hubungan antaragama menjadi alat pemersatu, sehingga terjalin sebuah hubungan. Dari hubungan itu kemudian dapat bekerjasama dalam bidang teologis dan sosiologis.

37 Watung A. Budiman, Al-Qur'an, Liberation and Pluralisme, Membebaskan yang Tertindas (Bandung : Mizan, 2000), h. 257.

${ }^{38}$ Farid Esack, Qur'an, Liberation and Pluralism an Islam Perspektive of Interreligious Solididarity against oppression (Oxford: One World, 1997). h. 83. 
Ketika melihat dampak positif dari dialog mutual seakan tidak ada sisi negatif dari penerapan teori ini. Apabila mutualisme dikaitkan dengan konflik sosial dan politik seakan tepat dan tanpa cacat. Dengan menghilangkan perbedaan (kesenjangan sosial yang menjadi penyebab awal konflik). Akan tetapi jika mutualisme sebagai model hubungan antaragama di mana setiap agama tidak ada perbedaan keimanan seseorang akan terkikis. Hal ini dikarenakan dalam beragama perlu sikap eksklusif dalam agamanya sebagai kemantapan dan penguat dalam memeluk agama.

\section{Penerapan Teori Mutualisme Paul Knitter dalam Hubungan Antarumat Beragama di Indonesia.}

India merupakan negara di mana Knitter melihat mutualisme, saat Knitter berada di sana. Pengalaman di India, Knitter bersentuhan dengan penindasan terhadap kelas-kelas bawah. ${ }^{39}$ Knitter menyebutnya pentingnya kebebasan dialog untuk menemukan agama. ${ }^{40}$ Faktanya Praxis, Hindus, Crhistians, Muslims bersamasama untuk melawan penindasan dan untuk belajar dari yang lain untuk bekerja bersama-sama melawan penidasan.

India merupakan tempat dimana dialog mutual antar umat dikembangkan. Karena menurut Knitter, kondisi India dengan dua wajah dalam satu wadah, yakni banyak agama dan kemiskinan. The many religionsand many poor, sehingga dialog mutual sangat dimungkinkan sebagai jalan keluar atas masalah kemiskinan yang mendera. Kerjasama saling menguntungkan antar umat beragama di India akan sangat membantu dan mengurangi kemiskinan, sehingga keberagamaan tidak sekedar pegakuan keberadaan agama lain. Dialog mutual menghasilkan suatu jalan keluar atas kemiskinan, secara sosiologi agama menjadi problem solving atas kejadian sosial. Belajar dari India, maka penerapan mutualisme di Indonesia sangat memungkinan.

Indonesia merupakan salah satu negara yang dalam keberagamannnya menganut paham pluralisme dalam beragama. Pluralisme di sini, diartikan sebagai menjunjung tinggi dan bersikap toleran terhadap eksistensi agama-agama lain. Dengan kata lain, eksistensi beberapa agama diakui dan dilingdungi oleh undang-undang. Ketuhanan Yang Maha Esa, merupakan sila pertama Pancasila yang merupakan bukti pengakuan negara atas agama-agama.

\footnotetext{
${ }^{39}$ Lidya Kambo Tandirerung, Liberative Dialogue a Comparative Analysis h. 23.

${ }^{40}$ Paul F. Knitter, One Earth Many Religion, h. 10.
} 
Realitas ini menjadikan hubungan antaragama di Indonesia sangat menarik untuk disimak. Dari beberapa agama yang diakui oleh Indonesia, potensi dialog antaragama menjadi hal yang idak dapat dinafikan dalam hubungan anatarumat beragama. Hal ini berarti Indonesia mampu menciptakan komunitas yang mampu mengayomi perbedaan pada setiap agama. Konsep interreligius semacam ini agaknya masih susah dijalankan, namun dengan adanya perbedaan justru menciptakan peluang dialog religius yang terbuka lebar.

Pluralisme dari pluralitas di Indonesia merupakan model yang menjunjung tinggi sikap toleransi terhadap agama di luar dirinya. Penolakan model ini memicu lahirnya konflik antaragama, baik konflik intern maupun konflik ekstern. Konflik atas penolakan konsep ini banyak ditemui, inilah buki konkrit akan pentingnya pemahaman pluralisme. Maka pemahaman model ini menjadi jalan tengah dalam dialog dan hubungan antaragama.

Berdasarkan historinya, konflik tidak bisa terlepas dari rendahnya kesadaran masyarakat akan pentingnya kesadaran bermasyarakat. Kebersamaan ini mendukung kehidupan bersama saling menolong dan toleransi dalam kehidupan. Hal itu dapat teratasi dengan kesadaran akan pentingnya pluralisme yang ditanamkan sedini mungkin. Kecenderungan eksklusif harus tepat dalam implementasinya, sehingga ekslusif terhadap agamanya tidak menafikan yang ada di luarnya. Secara psikologi seseorang akan mudah memberi afirmasi terhadap kebenaran agama yang dianut, antara lain dengan menegasikan dan menyalahkan agama lain. Artinya, terdapat pribadi yang hanya dengan jalan menyalahkan agama lain maka ia akan lega dan merasa yakin dengan agama yang dianutnya. ${ }^{41}$ Kenyataannya ini menjadi suatu yang mustahil jika kebenaran satu yang ditonjolkan dengan pemahaman satu dan dibungkus dalam format satu pula.

Pertanyaan selanjutnya adalah mungkinkah keberagamaan itu merupakan suatu kenyataan alami suatu bangsa, ataukah justru keberagamaan itu menjadi suatu yang harus dimusnahakan. Kita perlu memahami akan kebenaran yang universal bahwa setiap agama memiliki perbedaan dan keyakinan yang berbeda. Tapi perlu diingat bahwa setiap pilihan terhadap agama itu hanya bersifat pribadi dan tidak mendatangkan masalah sosial maka sikap toleransi layak diterapkan. Namun sebaliknya apabila sudah sampai pada unsur provokasi terhadap yang sifatnya destruktif, tidak perlu adanya toleransi.

\footnotetext{
${ }^{41}$ Komaruddin Hidayat dan Muhammad Wahyuni Nafis, Agama Masa Depan Perspektif, h. 70.
} 
Toleransi bukan berarti diam saja terhadap yang lain, melainkan tetap mendakwahkan kebenaran agamanya dan berpegang teguh pada tatanan sosial kebersaman dengan menghargai hak-hak setiap individu. Tidak boleh ada justifikasi secara sosial, sebab Tuhan adalah pengadilan yang sesungguhnya. Melihat sejarah secara empiris banyak terjadi kekacauan yang membawa-bawa agama, maka perlu mencari suatu konsep dalam hubungan antarumat. Mencari solusi konsep hubungan antaragama yang lebih luas, diawali dengan menyatukan hubungan intern agama. Hal ini perlu, sebelum hubungan yang luas maka hubungan intern harus terbangun. Beberapa konflik yang terjadi biasanya dilatarbelakangi oleh etnis, suku dan kelompok tertentu. Agama lain selalu dimaknai sebagai suatu musuh, yang perlu dibasmi. Akhirnya muncul klaim pengkarfiran terhadap se-agama yang berbeda sekte maupun terhadap agama yang lain.

Mengakarnya truth of claim pada setiap individu tidak memberikan preposisi yang menguntungkan baik dari segi teologi ataupun sosial, namun justru akan menimbulkan sikap fanatik yang berlebihan sehingga menghantam sendi keimanan. Seperti yang terjadi di Gereja Katolik, tentang doktrin bahwa gereja adalah pusat keselamatan extra eccelesiam nulla salus (no salvation outside the crist). ${ }^{42}$ Hal inilah yang menjadikan arogansi untuk tidak saling hormat menghormati dan menghargai kenyakinan di luar gereja: the Bible very crearly teaches that crist is the only way to salvation. Jesus said, "I am the way and truth and the life. No one comes to the father except trught me." 43 (Jhon 14:6). ${ }^{44}$

Senada dengan Budhy Munawar Rachman, ayat di atas dalam prespektif orang bersikap eklusif sering dibaca apa adanya. Selain itu ada ungkapan yang selalu menjadi kutipan kebenaran dan keselamatan tidak ada dalam siapapun juga selain di dalam Dia, sebab di kolong langit ini, tidak ada nama lain yang diberikan kepada manusia yang olehnya kita dapat diselamatkan (kisah para rasul). ${ }^{45}$ Sehingga istilah tidak ada nama lain itulah yang menjadi simbol tentang tidak adanya keselamatan di luar Yesus Kristus. ${ }^{46}$ Setiap agama berhak mengatakan

\footnotetext{
${ }^{42}$ Mukti Ali, Pandangan Pluralisme Sebagai Jalan Pemersatu, h. 6.

${ }^{43}$ Perjanjian Baru, (Lembaga Alkitab Indonesia, the Gideons International), hal. 306.

${ }^{44}$ Sukidi Mulyadi, Teologi Inklusif Cak Nur, hal. xii.

${ }^{45}$ Mukti Ali, Pandangan Pluralism Sebagai Jalan, h. 6.

${ }^{46}$ Budhy MunawarRachman,Wajah Liberal Islam Indonesia (Jakarta: Grasindo, 2001), hal. 44-45.
} 
bahwa agama yang dianut adalah benar, namun dalam posisi yang bersamaan harus menghargai hak orang lain sebagai bentuk toleransi dengan bersikap sama. ${ }^{47}$

Secara demografi sensus agama yang ada di Indonesia adalah Islam 87,21\%, Kristen 6,04\%, Katolik 3,58\%, Hindu 1,83 \%, Buddha 1,03, lainnya 0,32.48 Hubungan antarumat beragama sangat diperlukan dalam keberagama di Indonesia, karena beberapa konflik yang terjadi di beberapa tempat disebabkan karena unsur ketidaksamaan keadilan, kesenjangan sosial, tumpang tindih politik serta pengaruh kebudayaan. Diantara konflik berskala besar dan berlangsung lama, seperti kerusuhan di Ambon (mulai 1998), Poso (mulai 1998), Maluku Utara (2000), dan beberapa tempat lain. ${ }^{49}$ Sebab yang paling mendasari dari konflik atas nama agama di beberapa wilayah tidak lain adanya kesenjangan sosial. Konflik ini semakin kuat dan besar dengan adanya keikutsertaan agama di dalamnya.

Secara sosiokultural masyarakat Indonesia dalam beragama sangat menjunjung tinggi arti pentingnya agama sebagai way of live. Sikap eksklusif beragama tercermin dalam setiap tidakan dan ekspresi beragamanya. Sehingga apabila agamanya tersentuh atau bahkan diganggu oleh orang lain maka akan menimbulkan konflik yang besar. Adapun kemungkinan penerapan teori mutualisme Knitter dalam hubungan antarumat beragama di Indonesia untuk meminimalisir adanya konflik bukan lagi masalah kesakralan dalam beragama. Hubungan antarumat beragama yang memungkinkan penerapan teori mutualisme adalah beberapa hal yang berkaitan erat dengan politik, sosial, ekonomi ,budaya dan lingkungan.

Manusia Indonesia yang ialah manusia yang mengabdi pada ajaran-ajaran agama mereka dengan mengasihi terhadap sesama. Artinya bukan setiap minggu datang ke gereja, melakukan konfensional atau datang ke masjid dan berpuasa saja, tetapi dalam bertingkah laku setiap hari mencerminkan ajaran agama. ${ }^{50}$ Indonesia tidak dapat dipisahkan dengan gotong royong, guyub rukun dan saling menolong antar sesama. Sebagai sosial manusia tidak dapat hidup tanpa bantuan orang lain, tidak mampu hidup sendiri oleh karenanya penerapan teori mutualisme sangat tepat. Jiwa gotong royong dan saling menolong sudah

47 Abdul Muqsith Ghazali, Argumen Pluralisme Agama, Membangun Toleransi Berbasis Alquran (Jakarta: Kata Kita, 2009), hal. 9.

48 Agus Pahrudin Dkk, Harmonisasi Agama dan Budaya dan Budaya Di Indonesia (Jakarta: Balai Penelitian dan Pengembangan Agama, 2009), h. 147.

49 Yusuf asry, Menelusuri Kerifan Local di Buminusantara: Melalui Dialog Pengembangan Wawasan Multicultural Antara Pemuka Agama Pusat dan Daerah di ProvinsiMaluku Utara, Papua, dan Maluku (Jakarta: Badan Litbangdan Diklat Kementerian Agama, 2010), h. 20.

${ }^{50}$ Mochtar Lubis, Manusia Indonesia (Jakarta: Yayasan Obor Indonesia, 2001), h. 5. 
mengakar dalam tindakan secara naluriyah. Selain itu hal kecil yang berlaku pada masyarakat desa misalnya kerja bakti tanpa memandang agama dan golongan. Melihat wajah indonesia yang kental dengan sikap kebersamaan, kerukunan, kekeluargaan dan gotong royong, maka penerapan teori mutualisme adalah suatu yang tepat. Penerapan ini terlepas agama apa dan dari golongan mana.

\section{KESIMPULAN}

Hubungan antaragama merupakan suatu keharusan di Indonesia, hal ini dilihat dari kompleksitas agama. Pluralitas merupakan kenyataan yang tidak terbantahkan, tetapi peran pemeluk agama dalam mempertahankan kebenaran agamanya sering kali menimbulkan perpecahan. Klaim kebenaran yang tunggal menjadikan konflik antara agama. Maka perlu dirumuskan dalam suatu hubungan antaragama. Wujud dari hubungan yang mutual dari pemeluk agama ialah dialog antaragama.

Latar belakang konflik selain di atas ialah adanya ketidakadilan pada bidang politik, ekonomi dan budaya, maka tawaran Knitter yang dapat diterapkan di Indonesia adalah pola hubungan yang mutual. Dialog yang mutual dapat diwujudkan dengankerjasama dalam bentuk nyata. Peran FKUB tidak sekedar wacana dalam bingkai kebersamaan tetapi diimplementasikan dalam kegiatan. Dialog menjadi salah satu cara dalam pengimplementasinnya.

\section{DAFTAR PUSTAKA}

Ali, Mukti, Asal Usul Agama (Yogyakarta: Yayasan Nida, 1968) , Ilmu Perbandingan Agama di Indonesia (Bandung: Mizan, 1988)

, Pandangan Pluralism Sebagai Jalan Pemersatu, Jurnal Ijtihad, (Jakarta: UIN Syarif Hidayatullah vol.5, 2003).

Asry, M. Yusuf, M. Si,. APU, Menelusuri Kearifan Lokal di Bumi Nusantara: Melalui Dialog Pengembangan Wawasan Multicultural Antara Pemuka Agama Pusat dan Daerah di Provinsi Maluku Utara, Papua, danMaluku, (Jakarta: Badan Litbang dan Diklat Kementerian Agama, 2010)

Bertens, K., Filasafat Barat Dalam Abad XX (Jakarta: PT Gramedia, 1981)

Budiman, Arief, Dimensi Sosial Ekonomi Dalam Konflik Antar Agama diIndonesia (Yogyakarta: DIAN/Interfidei, 1995)

Bustanudi, Agus, Agama dan Tantangan Sosial (Jakarta: UI Press, 2010) 
Budiman, Watung A., Al-Qur'an, Liberation and Pluralisme, Membebaskan yang tertindas (Bandung: Mizan, 2000)

Coward, Harold, Pluralisme, Tantangan Bagi Agama-agama (Yogyakarta: Kanisius, 1989)

Esack, Farid, Qur'an, Liberation and Pluralism an Islam Perspektive of Interreligious Solididarity against oppression (Oxford: One World, 1997)

Ghazali, Abd. Muqsith, Argumen Pluralisme Agama, Membangun Toleransi Berbasis Alquran (Jakarta: kata Kita, 2009)

Grose, George B. dan Benjamin J Hubbard, Tiga Agama SatuTuhan (Bandung: Mizan, 1998)

Hadi, Sutrisno, Metode Research (Yogyakarta: Andi Offset, 1987)

Hamarsma, Harry, Tokoh-TokohFilsafatBarat Modern (Jakarta: PT Gramedia, 1983)

Hendropuspito, D. Sosiologi Agama (Yogyakarta: PustakaPelajar, 1986)

Hick, Jhon, God Has Many Names (Philadelpea: The Westminster Press, 1980) Jhon, God And Universe Of Faith (New York: St. Martin's Press)

Hidayat, Komaruddin dan Muhammad WahyuniNafis, Agama Masa Depan Perspektif Filsafat Perenial (Jakarta: Paramadina, 1995)

Knitter, Paul F, Introduducingthe Teologiesof Religions (New York: Marynoll, 2002) - MenujuTeologiPembebasan Agama-Agama,di dalamMitosKeunikan Agama Kristen, eds. John Hick dan Paul F. Knitter (Jakarta: BPK Gunung Mulia, 2001)

One Erath Many Religions: Multifaith Dialogue and Global Responding (New York: Orbis Books, 1995) , No Other Name (New York: Orbis Books, 1985) Pengantar ke Dalam Teologi Agama-Agama (Yogyakarta: Kanisius, 2008) Satu Bumi Banyak Agama (Jakarta: BPK GunungMulia, 2004)

Kung, Hans dan Karl-josef Kuschel, Etik Global (Yogyakarta: Sisiphus, 1999)

Lubis, Mochtar, Manusia Indonesia (Jakarta: Yayasan Obor Indonesia, 2001)

Majid, Nurcholis, Tiga Agama SatuTuhan (Mizan: Bandung, 1999) 
Mulyadi, Sukidi, Teologi Inklusif Cak Nur (Jakarta: Kompas, 2001)

Noeng, Muhadjir, Metode Penelitian Kualitatif (Yogyakarta: Rake Sarasin, 1989)

Pahrudin, Agus, dkk, Harmonisasi Agama danBudayadi Indonesia (Jakarta: Balai Penelitian dan Pengembangan Agama, 2009)

Rachman, Bhudy Munawar, Wajah Liberal Islam Indonesia (Jakarta: Grasindo, 2001)

Tandirerung, Lidya Kambo, LiberativeDialogue a comparative analysis of theproposal of Paul Knitter and FaridEsack for liberative dialogue of religions and their contribution to Muslim-Chistian relation in Indonesia (Yogyakarta: UGM, 2004)

Thomas F. O'deo, Sosiologi Agama (Jakarta: PT Rajawali, 1985) 